\title{
Genesis of pyrobitumen in a newly discovered shale oil reservoir- Kongdian Formation in the Cangdong Sag of Bohai Bay Basin, China
}

\author{
LI WANG ${ }^{1}$ AND YUANJIA HAN ${ }^{2}$
}

${ }^{1}$ China University of Geosciences(Wuhan)

${ }^{2}$ China University of Geosciences

Presenting Author: liwangcug@163.com

Pyrobitumen vein is identified in the newly discovered shale oil reservoir, i.e., the Kongdian Formation in Cangdong Sag of Bohai Bay Basin, China. Considering the magmatic rocks are embedding within Kongdian Formation, the over-mature pyrobitumen is believed to be formed by magma or associated hydrothermal fluid activities.

(1) Pyrobitumen illustrates a strong heterogeneity mosaic structure. The random reflectance of pyrobitumen is $4.44 \%$ in average, which is roughly the same as the reflectance obtained by laser Raman spectroscopy $(3.89 \% \sim 4.56 \%)$. The formation temperature of pyrobitumen revealed by Raman spectroscopy is $324^{\circ} \mathrm{C} \sim 354^{\circ} \mathrm{C}$. This is in line with transmission electron microscopy observations, in which the lattice fringes image show features of local orientation. (2) Pyrobitumen is coexisting with hydrothermal fluid associated minerals such as chlorite, barite, natrolite and analcime filling veins of mudstone, in which chlorite, chalcopyrite, pyrite, analcime are also identified in mudstone matrix. (3) The positive Eu anomaly of barite and chlorite in veins of mudstone, the positive $\mathrm{Ce}$ anomaly and negative Eu anomaly of chlorite in mudstone matrix, the similar distribution pattern in rare earth elements between natrolite and basalt, and the $\mathrm{Co} / \mathrm{Ni}$ of pyrite is $0.79 \sim 1.89$, all indicating their origin of hydrothermal fluid associated with magmatic activities. (4) Raman spectroscopy and thermovaporisation gas chromatography reveal that gaseous hydrocarbon inclusions are developed in calcite, barite, and natrolite. (5) The $n$-alkanes of pyrobitumen extracts are symmetrically distributed around the main peak $n-\mathrm{C}_{23}$. The extracts have high phytane abundances, $\mathrm{Ts} / \mathrm{Tm}$ ratio less than 1 and $\mathrm{V}$ type distribution of $\mathrm{C}_{27-29}$ sterane. The stable carbon isotope composition of pyrobitumen extracts (saturates $=-29.2 \%$, aromatics $=-28.4 \%$ ) are different from that of source rock extracts from Kongdian Formation (saturates= $-32.9 \sim-32 \%$, aromatics $=-30.8 \sim-30.4 \%$ ), Carboniferous-Permian strata (saturates $=-28.5 \sim-26.4 \%$, aromatics $=-27.5 \sim-24.3 \%$ ) and

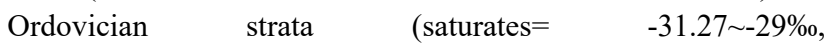
aromatics $=-31.94 \sim-29.7 \%$ ), and it is speculated that pyrobitumen is derived from Carboniferous-Permian strata with some extent of mixture from other source rocks. 